\section{ECONOMICS}

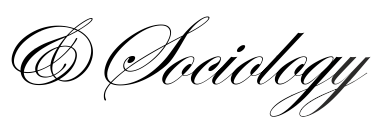

Costa J., Rodrigues A. C., \& Ferreira M.R. (2020). Organizational culture in social economy organizations. Economics and Sociology, 13(3), 155-170. doi:10.14254/2071-789X.2020/13-3/10

\title{
ORGANIZATIONAL CULTURE IN SOCIAL ECONOMY ORGANIZATIONS
}

\author{
Joana Costa \\ CEOS.PP / ISCAP / P.Porto, \\ Porto, Portugal \\ E-mail: \\ joanapatriciacosta1@gmail.com
}

Ana C. Rodrigues
CEOS.PP / ISCAP / P.Porto,
Porto, Portugal
E-mail: anarodrigues@iscap.ipp.pt
ORCID: 0000-0002-6238-1385

Marisa R. Ferreira

CIICESI, ESTG, Politécnico do

Porto, Porto, Portugal

E-mail:mferreira@estg.ipp.pt

ORCID: 0000-0003-4194-9127

Received: January, 2020

1st Revision: June, 2020

Accepted: September, 2020

DOI: $10.14254 / 2071-$

789X.2020/13-3/10

JEL Classification: L31, M14

\begin{abstract}
Over the last years, Social Economy Organizations have undergone significant organizational changes. The purpose of this article is to analyze the organizational culture, assessed through the Competing Values Framework (CVF). A multi case-study approach was performed, in three Cooperatives for Education and Rehabilitation of Citizens with Disabilities (CERCI), collecting qualitative and quantitative data. Applying the qualitative analysis suggested by the CVF indicated that there were no differences among the studied organizations, nor between the culture types within each of them. Statistical analysis confirmed differences in organizational culture among the three CERCIs. Clan culture is more prevalent than the other types of culture, and there are differences between CERCI 1 and 2, and CERCI 1 and 3 regarding adhocracy and hierarchy, and adhocracy, respectively. These differences show the framework's sensibility for this type of organizations. The added value of this paper entangles with literature and practical implications. It adds to the social economy theoretical field demonstrating that a well-known model is adequate, and therefore enables the improvement of organizational knowledge and study in this sector, as well as organizational development. Extends the model itself confirming its wider usage and the pertinence of statistical analysis to have a more accurate diagnose of the organizational culture, and therefore management action.
\end{abstract}

Keywords: social economy organizations, organizational culture, competing values framework, CERCIs

\section{Introduction}

In recent years, several factors have contributed to the growing pressure on SEO. Increasingly these organizations are required to improve efficiency and effectiveness despite financial cutbacks and growing social demand for services (Carvalho, Ferreira, \& Silva, 2019; Kellner, Townsend, \& Wilkinson, 2016). In the national and European context, and at a time of global economic and environmental crisis, academic and policy discussions are re-emphasizing the importance of the social economy in providing an alternative development model that reconnects communities with their resource-base (Martins, 2010; Sdrali, Goussia-Rizou, Giannouli \& Makris, 2016; Sonnino \& Griggs-Trevarthen, 2013). In Portugal, the SEO face 
significant challenges and their eventual professionalization will make them become more robust and, necessarily, more innovative in what concerns the solution of the existing social problems in the society (Potts \& Hartley, 2015). One of these challenges is related to the problematic of mental health and/or intellectual disability.

In the SEO, as well as in other organizations, the organizational culture results it is reinforced and/or changed by five factors: the history of the organization; organizational structure and internal relations; management practices or way of conducting businesses in the daily life; the existing system of communication between volunteers, administrative and directive body; systems of rewards (Orsi, Marino, Rossi, Bertoia, \& Shiniashiki, 2005), it is understood that there are no significant divergences regarding the factors that influence the organizational culture, both in the organizations with lucrative purposes and in the SEO (Orsi et al., 2005).

In the last few decades, the social economy has asserted itself, particularly in its capacity to cooperate efficiently for the resolution of new problems. It is considered to be an essential sector to a sustainable and steady economic development, adjusting the services to the necessities, valuing the economic activities to the service of the necessities and, also deepening and strengthening the economic democracy (Buendía-Martínez, álvarez-Herranz, \& Menéndez, 2020; Chaves-Avila \& Gallego-Bono, 2020; Chaves \& Monzón, 2012). The organizations that provide services in the area of mental disability - CERCIs (Cooperatives for Education and Rehabilitation of Citizens with Disabilities), in particular, have an essential role in the intervention among the citizens with intellectual disabilities/multiple disabilities in Portugal (FENACERCI, 2015).

In recent years, the study of the organizational culture has become one of the most common themes (Boone, 2014; Jaskyte \& Dressler, 2005; Romero \& Pérez, 2003) and it has raised great interest in the academic and scientific debate, establishing itself as an object of analysis of research in management schools and organizations (Krajcsák, 2018; Martínez, 2009). The SEO are, by definition, organizations of collective nature with shared power and, as such, its culture will not be copied from the intentions and personality of a single leader, but from a set of people who have a collective project (Chaves \& Monzón, 2012).

The Competing Values Framework from Quinn \& Rohrbaugh (1983) is the model adopted for this study. This framework aims to organize the different beliefs, values and shared standards of behaviour that define the culture of an organization, translating into an efficient instrument to determine the types of culture of the organization, to interpret its assets and to study the culture at a comparative level (Santos, 1998). It is one of the 40 more significant models of the history of the management (Have, Have, \& Stevens, 2003) and it is used in hundreds of organizations in the whole world to promote the success and to improve the effectiveness of the organization.

\section{Literature review}

\section{Social economy organizations}

The sector of the Social Economy gathers organizations where there is no appropriation of profit generated by the organization, where the existing asset is impersonal and where one works for a particular purpose or mission. The SEO emerge from the desire to foster the development and the satisfaction of necessity of the civil society, improving the social cohesion (Sonnino \& Griggs-Trevarthen, 2013; Velden, Alvarez, Sá, Meira, \& Ramos, 2014).

In accordance with the António Sérgio Cooperative for the Social Economy (CASES), Social Economy is defined as follows: "the set of companies of free adhesion and autonomy of 
decision, democratically organized, with legal personality, created to satisfy the needs of its members in the market, producing goods and services, and in which the distribution of any surpluses of the financial year and the decision-making process is not related to the individual capital of the members, that will have a vote each. There are included in it, namely, the cooperatives, the mutual societies, the associations and the foundations, as well as social companies and non-profit voluntary entities that produce services of non-market for the families, and whose possible surpluses cannot be appropriated by the economic agents who created, control or finance them" (Observatório da Economia Social em Portugal (OBESP), 2011, p. 11).

All the SEO present two crucial characteristics - the concern with the people and the concession of great importance to the essential aspects for its development, in particular: the respect for the human dimension; the fight against the social exclusion; the will to promote spaces of individual accomplishment; a democratic and participated vision of the organization; the concept of the organizational mission that includes it in the social fabric (without reducing it to a mere economic one-dimensionality); the management autonomy; the importance of the people and the work over the capital; the assumption of responsibilities both individual and collective; the development of a high degree of share capital (OBESP, 2011).

Nowadays, the Social Economy is, clearly, a sector that contributes significantly for the sustainable growth, the job creation and a fairer distribution of income and wealth. It gathers all the conditions to adjust profitability, social inclusion and systems of democratic governance, working with the public and private sectors in the provision of services suitable to the needs (Calderón-Milán, Calderón-Milán, \& Barba-Sánchez, 2020; Monzón-Campos \& Chaves-Ávila, 2012; Płachciak, 2009). At the same time, the Social Economy is, sometimes, recognized as a critical attitude towards the society, as well as an early glimpse of a brighter future (OBESP, 2011).

\section{CERCIS}

The SEO have been a recognized intervention in the area of the mental health and/or intellectual disabilities, in a clear active demonstration of social solidarity. In Portugal, after 1974, as an answer to the lack of support structures to the family, particularly in the fields of education and rehabilitation, a vast movement of creation of associations and cooperatives was unchained. The CERCIs (Cooperatives for Education and Rehabilitation of Citizens with Disabilities) are an example of success and a symbol of great experience in the shelter and support, mainly of children, youngsters and adults with disabilities and incapacities (Guerra, 2008). The CERCIs appeared in 1975, after the Portuguese revolution of 25th of April 1974, resulting from the absence of answers in the area of the education of citizens with special educational needs. The movement was entitled "Movimento CERCI", and it was an initiative created by parents, experts and people concerned with the problematic of citizens with intellectual disabilities (INE \& CASES, 2013; Rodrigues, 2015). The CERCIs are service provider organizations whose main objective is to structure adequate and necessary answers for the development of children, youngsters and adults with disabilities, as well as, to support and promote in a diversified manner their inclusion in the society. These organizations are nonprofit social solidarity cooperatives recognized as Entity of Public Utility (FENACERCI, 2015). The CERCIs are framed in the branch of the social solidarity. The majority of the CERCIs are represented by the FENACERCI (53 associates), the national federation of social solidarity cooperatives. Nowadays, its mission is to promote the creation of conditions that protect the interests and rights of citizens with disabilities and their families (FENACERCI, 2015). 


\section{Organizational culture in the social economy organizations}

The culture is an aspect of particularly importance functioning in all the organizations, considering that this aspect assumes a higher proportion in the SEO, insofar as in these, people usually believe and trust in the cause for which they work, and they make it a motivation factor (Orsi et al., 2005).

Improving the management of SEO must occur through the consideration of aspects relating to the basic structure (Álvarez González \& Sanzo Pérez, 2009). In these SEO, as well as in other organizations, strong organizational culture might have difficulties in implementing new ways of functioning, in responding to changes in the external environment, and in generating new solutions to problems that arise (Jaskyte \& Dressler, 2005). At the same time, it is understood that there are no large discrepancies concerning the factors that influence the organizational culture, in both the organizations with lucrative purposes and the SEO (Martínez, 2009; Orsi et al., 2005).

However, there are authors (Ruwer \& Canoas, 2009) who think that the culture is different between the profit-making and non-profit organizations. The same authors refer that the SEO withhold features and consist of specific cultural patterns, different from the characteristic patterns of the private organizations with lucrative purposes or public institutions. Organizational culture is particularly important in SEO, primarily due to the features and the motivations of the people who work in these institutions (Parente, 2010). The cultures of the profit-making and non-profit organizations are different from one another, having some typical traces, and this is what characterizes them. In the SEO, the culture can be different by its nature. The emotional tone associated with a particular cause mobilizes pertinent and important actions for the civil society. In this context, it is highlighted the role of the leader in understanding the cultural values of the organization, in order to transform these values in a driving force for the achievement of the objectives, overcoming possible ambiguities and group differences. Thus, in the SEO the strategic leadership is defined by clear goals and cultural values that develop people towards the shared objectives (Boone, 2014; Orsi et al., 2005).

In this study, one considers that the organizational culture of the SEO will be different from the profit-making organizations. However, its measurement will be able to follow the same parameters, since the organizational culture can be studied using instruments that are valid and suitable in the two scenarios. It will be adopted the Competing Values Framework (Quinn \& Rohrbaugh, 1983) as the model to assess the culture in the SEO. Since this model was already applied previously in studies carried in SEO (Ferreira, Rodrigues, \& Marques, 2015; Jaskyte, 2010; Pinho, Rodrigues, \& Dibb, 2014), and for being one of the models more used in the management area (Lopes, 2010). Moreover, it characterizes the organizations according to the shared cultural traces to all the human organization, expressing itself in an efficient instrument to identify the types of culture of the organization and to understand its assets (Santos, 1998).

"The majority of the authors argues that there are narrow relations between the type of organizational culture and the style of leadership practised in each organization" (Lopes \& Reto, 1988, pp. 31). As the SEO are, by definition, organizations of collective nature with shared power, its culture will not be copied from the intentions and personality of a single leader, but from a set of people who have a collective project (Parente, 2010). Thus, one must consider the different theoretical points of view that integrate the dynamics of the culture of the organizations, so that it becomes possible to understand the importance of the organizational culture in a somewhat particular perspective: the visible reality for the people and in the people (Lopes \& Reto, 1988; Romero \& Pérez, 2003).

Culture may be considered as an internal and external variable, closely related to the type of activity and precise situations in work referring to the division of the labour, authority 
and information, as well as to the adjacent environment (Chumg, Cooke, Fry, \& Hung, 2015; Souder, 2016). In the case of the SEO, and in comparison, with the context where they act, the stakeholders are a key factor of their activity (Boerner \& Jobst, 2011; Wellens \& Jegers, 2014). Therefore, the analysis of the organizational culture of these organizations will have to include several perspectives among which the standpoint of the competent bodies, workers, volunteers, users, funders and community (Giffords \& Dina, 2003).

\section{Competing values framework}

The model from Quinn \& Rohrbaugh (1983) entitled Competing Values Framework was the model chosen to analyse the data from this study since it allows to relate the culture with the organizational performance. This model was initially developed to explain the existing cultural profiles in different organizational models, and it is mentioned as one of the 40 models in the history of management (Have et al., 2003), widely used in the organizational research, that is to say, when the organizational culture and the performance are related (Gregory, Harris, Armenakis, \& Shook, 2009), since it allows to think the organizational effectiveness in an integrated manner, not valuing only a single set of values and criteria (Cameron \& Quinn, 2011).

The Competing Values Framework conceptualized by Quinn \& Rourbaugh (1983) is represented by two axes: the horizontal axle (it varies between the internal orientation and the external orientation) and the vertical axle (it varies between flexibility and the dynamics and the stability and the control). Three dimensions are distributed around it: flexibility versus control, internal orientation versus external orientation and processes (means) versus results (purposes), and whose combination results in four quarters: clan, adhocracy, market and hierarchy (Cameron \& Quinn, 2011). The four types of organizational culture presented above emphasize certain aspects, and an organization is characterized by having a particular type of culture when it possesses mainly more characteristic of a specific quadrant. However, all the organizations present attributes of all the four types of culture (Rodrigues \& Caetano, 2013, 2015). The contrasting nature of the quadrants is revealing of a paradoxical and complex organizational functioning, whose basis, that is to say, the organizational culture, will also be itself the expression of such contrasts. The way how the balancing of contrasting poles expresses themselves can be seen as an indicator of the degree of complexity of the organizational culture (Bligh \& Hatch, 2011; Jaskyte \& Dressler, 2005). This model characterizes the organizations in accordance with the cultural traces shared by the entire human organization, expressing itself in an efficient instrument to define the types of culture of the organization and to interpret its assets (Santos, 1998). Currently, it is used in hundreds of organizations in the whole world to promote the success and to improve the organizational effectiveness, allowing to think the organizational effectiveness in an integrated manner, without valuing only a single set of values and criteria (Neves, 2000). When considering the organizational culture and the corresponding values, the model presents the following structure (Figure 1). 


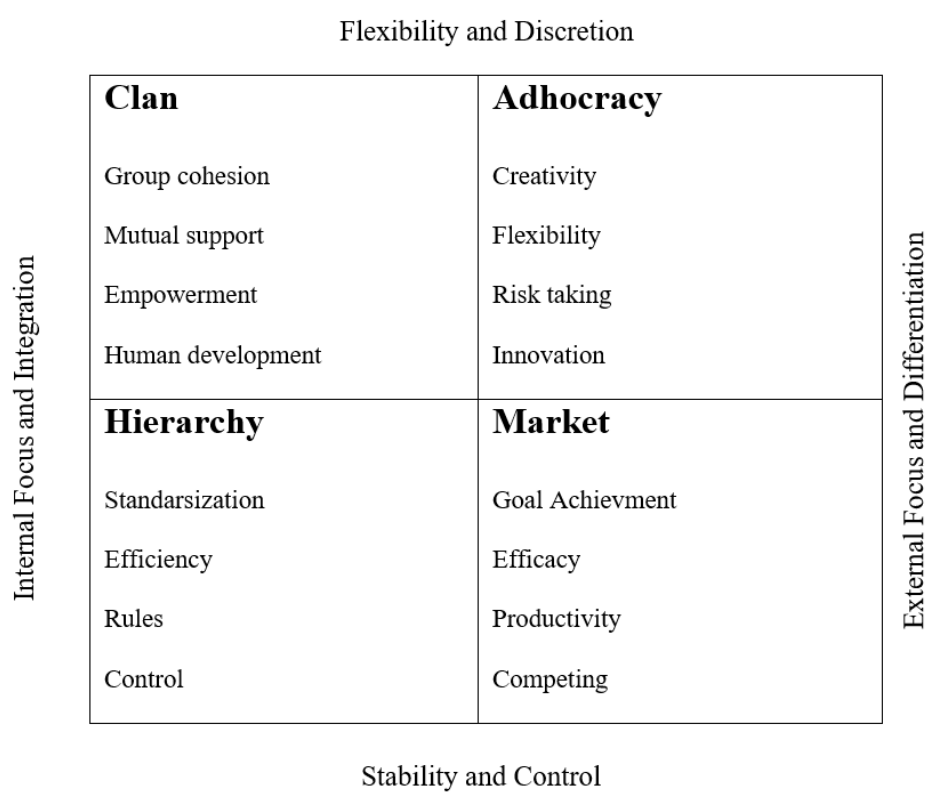

Figure 1. Competing values framework

Source: Quinn \& Rohrbaugh, 1983

\section{Methodological approach}

A multiple cases study approach was performed, resorting to quantitative and qualitative methodologies to diagnose the organizational culture in CERCIs. In Portugal there are 53 associates of FENACERCI, 17 of them in the Northern Region. The distribution of the Portuguese population with disabilities, by region, follows the same trend as the distribution of the total resident population, with a higher population incidence in the North (34\%), followed by Centre (26\%) and the Lisbon Metropolitan Area (24\%) (Pinto \& Pinto, 2017), so we decided to choose three CERCIs in the Northern Region of Portugal. Websites and activities and accountability reports regarding the year 2015 were analysed to characterize the organizations. A convenience sample of 142 employed staff were inquired to characterize the organizational culture. Most of the delivered questionnaires were filled $(80.7 \%)$.

The organizational culture was analysed through the Competing Values Framework (Cameron \& Quinn, 2011), and the instrument used to survey the employees was the OCAI (Organizational Culture Assessment Instrument) built by Cameron \& Quinn (2011), translated and adapted from Portuguese (Rodrigues \& Caetano, 2013). This instrument is a validated research method to diagnose the organizational culture. Moreover, the OCAI is founded in a methodology based on the elaboration of individual inquiries (Cameron \& Quinn, 2011). The survey has 24 items, regarding six dimensions: dominant characteristics, organizational leadership, management of employees, organizational glue, strategic emphasis, and success criteria.

Organizational culture data were analysed in three different ways: (1) qualitative, following authors' guidelines to verify differences between culture types within each organization; (2) quantitative, Kruskal-Wallis test to demonstrate differences between organizations; and (3) quantitative, paired-sample T-test to verify differences between culture types within each organization.

Table 1 presents case-studies and sample characteristics. The three CERCIs were founded in the same year (1976) each by a group of parents whose children did not have support for education and daily care. The CERCI 1 has 89 employees, and $100 \%$ of responses of 
delivered surveys. CERCI 2 has 68 employees, and 51,4\% of delivered surveys. And CERCI 3 has 72 employees and a $100 \%$ response rate of the delivered surveys. In all three institutions, the majority of paid staff is between 26 and 50 years old. The average number of years in school is the 12th grade in CERCI 3, which is the higher level of education among the three organizations.

Table 1. The case-studies and sample characteristics

\begin{tabular}{|c|c|c|c|c|c|}
\hline \multirow{2}{*}{ Data } & & \multicolumn{3}{|c|}{ Organization } & \multirow{2}{*}{ Total } \\
\hline & & CE1 & CE2 & CE3 & \\
\hline Number of workers & & 89 & 68 & 72 & 233 \\
\hline \multirow{3}{*}{ Responses to the survey } & Number of delivered surveys & 69 & 70 & 37 & 176 \\
\hline & Total number of responses & 69 & 36 & 37 & 142 \\
\hline & $\%$ of responses of delivered surveys & $100 \%$ & $51,4 \%$ & $100 \%$ & $80,68 \%$ \\
\hline CERCI founding year & & \multicolumn{4}{|c|}{1976} \\
\hline Population served in 2015 & & 2645 & 560 & 152 & 3357 \\
\hline \multirow{6}{*}{ Respondents' age } & Up to 25 years & 4 & 0 & 4 & 8 \\
\hline & $\%$ Up to 25 years & $5,8 \%$ & $0 \%$ & $10,8 \%$ & $5,6 \%$ \\
\hline & $26-50$ years & 49 & 30 & 26 & 105 \\
\hline & $\% 26-50$ years & $71 \%$ & $83,3 \%$ & $70,3 \%$ & $73,9 \%$ \\
\hline & more then 50 years & 16 & 6 & 7 & 29 \\
\hline & $\%$ more then 50 years & $23,2 \%$ & $16,7 \%$ & $18,9 \%$ & $20,4 \%$ \\
\hline \multirow{6}{*}{$\begin{array}{l}\text { Respondents' number of } \\
\text { years in school }\end{array}$} & Up to 9 th grade & 29 & 16 & 10 & 55 \\
\hline & $\%$ Up to 9 th grade & $42,6 \%$ & $47,1 \% \%$ & $27,8 \%$ & $38,73 \%$ \\
\hline & Up to 12 th grade & 13 & 7 & 16 & 36 \\
\hline & $\%$ Up to 12 th grade & $19,1 \%$ & $20,6 \%$ & $44,4 \%$ & $25,3 \%$ \\
\hline & Higher Education & 26 & 10 & 10 & 46 \\
\hline & $\%$ Higher Education & $38,2 \%$ & $32,4 \%$ & $27,8 \%$ & $32,4 \%$ \\
\hline
\end{tabular}

\section{Results}

Through the quantitative part of the research, the focus was on data collecting, processing, and analysis. A nine-level Likert scale was used to measure the perceptions and assessments of the respondents, on the dependent variable (transitional crisis), as well as the independent variables (heritage of socialism, geopolitics, nomenclature authorities, deficit of institutional changes, and neoliberal ideology), in a survey that was applied during the research. In measuring the dependent variable (transitional crisis), the scale marks were set from the lowest (1) to the highest (5). Regarding the independent variables, the negative impact was measured from the minimum negative (1) to the maximum (5) on the dependent variable. The survey included filling out 500 questionnaires for each country (Montenegro, Serbia, and Bosnia and Herzegovina), which made a total of 1,500 respondents. Collected data for this study were processed by SPSS software. According to the purpose defined in the hypothesis of work, descriptive statistics were used for the data analysis, correlation analysis, and multi-correlation. The multiple linear regression model was applied after (the method of least square), as well as hierarchical multiple regression model. 
Figure 2 presents the cultural profiles of the three investigated organizations. Analysing data following the criteria of Cameron \& Quinn (2011), the three case studies have a balanced cultural profile, which means that there is not only one type of culture that stands out from the others. To be considered a difference, there should be more than 1 point between types of culture. Considering all CERCIs, the Clan type of culture has a higher score, in none of the cases, the difference to the other types of culture is higher than one point.

CERCI 2

CERCI 1

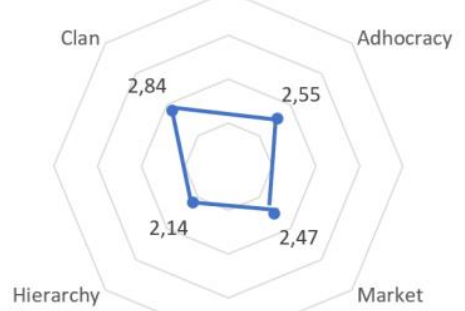

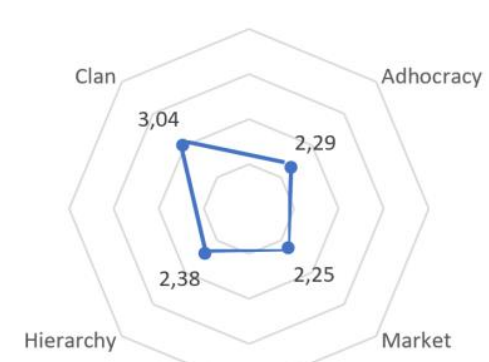

CERCI 3

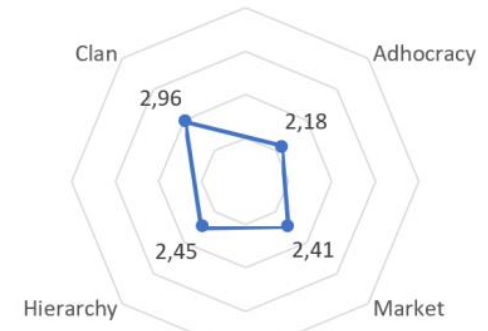

Figure 2. Cultural profiles of CE1, CE2 and CE3

To have a statistical measure of the differences between types of culture within each of the organizations, paired-samples T-test (table 1,2 and 3) were performed, and we identified statistically significant differences between culture types.

Regarding CERCI 1, on average, employees report higher expression of clan type of culture than the other types of culture $(p<.01)$. There are also differences between adhocracy and hierarchy, and between market and hierarchy. Generally, there is an intermediate to high size effect (above 30\% up to about 50\%) between cultures types mentioned, only between clan and market is a bit smaller (21\%) (see Table 2).

Table 2. CERCI 1 Paired Samples T test and Size Effect

\begin{tabular}{|c|c|c|c|c|c|c|c|}
\hline & & Mean & $\mathrm{N}$ & $\begin{array}{l}\text { Degrees } \\
\text { of } \\
\text { Freedom }\end{array}$ & $\mathrm{t}$ & $\begin{array}{c}\text { Sig. } \\
\text { (bilateral) }\end{array}$ & $\begin{array}{c}\text { Size effect } \\
\text { ( r) }\end{array}$ \\
\hline \multirow[t]{3}{*}{ Pair 1} & Clan & 17,07 & 69 & & & & \\
\hline & Adhocracy & 15,32 & 69 & & & & \\
\hline & Clan - Adhocracy & 1,75 & & 68 & 2,266 & 0,027 & 0,27 \\
\hline \multirow[t]{3}{*}{ Pair 2} & Clan & 17,07 & 69 & & & & \\
\hline & Market & 14,84 & 69 & & & & \\
\hline & Clan - Market & 2,23 & & 68 & 1,768 & 0,082 & 0,21 \\
\hline \multirow[t]{3}{*}{ Pair 3} & Clan & 17,07 & 69 & & & & \\
\hline & Hierarchy & 12,83 & 69 & & & & \\
\hline & Clan - Hierarchy & 4,25 & & 68 & 3,768 & 0,000 & 0,42 \\
\hline \multirow[t]{3}{*}{ Pair 4} & Adhocracy & 15,32 & 69 & & & & \\
\hline & Market & 14,84 & 69 & & & & \\
\hline & Adhocracy - Market & 0,48 & & 68 & 0,629 & 0,531 & \\
\hline \multirow[t]{3}{*}{ Pair 5} & Adhocracy & 15,32 & 69 & & & & \\
\hline & Hierarchy & 12,83 & 69 & & & & \\
\hline & Adhocracy - Hierarchy & 2,49 & & 68 & 3,477 & 0,001 & 0,39 \\
\hline \multirow[t]{3}{*}{ Pair 6} & Market & 14,84 & 69 & & & & \\
\hline & Hierarchy & 12,83 & 69 & & & & \\
\hline & Market - Hierarchy & 2,01 & & 68 & 4,190 & 0,000 & 0,45 \\
\hline
\end{tabular}


In CERCI 2, on average, employees report significant higher expression of clan type of culture than the other types of culture (adhocracy, market and hierarchy). There is a large size effect of the differences between cultures types (above 50\%) (Table 3).

Table 3. CE2 Paired Samples T test and Size Effect

\begin{tabular}{llllllll}
\hline & Mean & $\mathrm{N}$ & $\begin{array}{c}\text { Degrees of } \\
\text { Freedom }\end{array}$ & $\mathrm{t}$ & $\begin{array}{c}\text { Sig. } \\
\text { (bilateral) }\end{array}$ & $\begin{array}{c}\text { Size effect } \\
\text { ( } \mathrm{r})\end{array}$ \\
\hline Pair 1 & Clan & 18,56 & 36 & & & & \\
& Adhocracy & 13,72 & 36 & & & & \\
\hline & Clan - Adhocracy & 4,833 & & 35 & 5,161 & 0,000 & 0,66 \\
\hline Pair 2 & Clan & 18,56 & 36 & & & & \\
\hline & Market & 13,47 & 36 & & & & \\
\hline & Clan - Market & 5,083 & & 35 & 4,150 & 0,000 & 0,57 \\
\hline Pair 3 & Clan & 18,56 & 36 & & & & \\
\hline & Hierarchy & 14,28 & 36 & & & & \\
\hline & Clan - Hierarchy & 4,278 & & 35 & 3,831 & 0,001 & 0,54 \\
\hline Pair 4 & Adhocracy & 13,72 & 36 & & & & \\
\hline & Market & 13,47 & 36 & & & & \\
\hline Adhocracy - Market & 0,250 & & 35 & 0,272 & 0,787 & \\
\hline Pair 5 & Adhocracy & 13,72 & 36 & & & & \\
\hline & Hierarchy & 14,28 & 36 & & & & \\
\hline Pdhocracy - Hierarchy & $-0,556$ & & 35 & $-0,554$ & 0,583 & \\
\hline Pair 6 & Market & 13,47 & 36 & & & & \\
\hline & Hierarchy & 14,28 & 36 & & & & \\
\hline
\end{tabular}

In CERCI 3, on average, employees report significant higher expression of clan type of culture than the other types, with an intermediate to high effect (more than 30\%) (Table 4).

Table 4. CERCI 3 Paired Samples T test and Size Effect

\begin{tabular}{|c|c|c|c|c|c|c|c|}
\hline & & Mean & $\mathrm{N}$ & $\begin{array}{l}\text { Degrees of } \\
\text { Freedom }\end{array}$ & $\mathrm{t}$ & $\begin{array}{l}\text { Sig. } \\
\text { (bilateral) }\end{array}$ & $\begin{array}{l}\text { Size } \\
\text { effect ( } r)\end{array}$ \\
\hline \multirow{3}{*}{ Pair 1} & Clan & 17,96 & 37 & & & & \\
\hline & Adhocracy & 13,07 & 37 & & & & \\
\hline & Clan - Adhocracy & 4,89 & & 36 & 3,691 & 0,000 & 0,52 \\
\hline \multirow[t]{3}{*}{ Pair 2} & Clan & 17,96 & 37 & & & & \\
\hline & Market & 14,43 & 37 & & & & \\
\hline & Clan - Market & 3,53 & & 36 & 1,921 & 0,000 & 0,30 \\
\hline \multirow[t]{3}{*}{ Pair 3} & Clan & 17,96 & 37 & & & & \\
\hline & Hierarchy & 14,73 & 37 & & & & \\
\hline & Clan - Hierarchy & 3,23 & & 36 & 1,894 & 0,001 & 0,30 \\
\hline \multirow[t]{3}{*}{ Pair 4} & Adhocracy & 13,07 & 37 & & & & \\
\hline & Market & 14,43 & 37 & & & & \\
\hline & Adhocracy - Market & $-1,36$ & & 36 & $-1,529$ & 0,787 & \\
\hline \multirow[t]{3}{*}{ Pair 5} & Adhocracy & 13,07 & 37 & & & & \\
\hline & Hierarchy & 14,73 & 37 & & & & \\
\hline & Adhocracy - Hierarchy & $-1,66$ & & 36 & $-1,685$ & 0,583 & \\
\hline \multirow[t]{3}{*}{ Pair 6} & Market & 14,43 & 37 & & & & \\
\hline & Hierarchy & 14,73 & 37 & & & & \\
\hline & Market - Hierarchy & $-0,30$ & & 36 & $-0,294$ & 0,284 & \\
\hline
\end{tabular}

A Kruskal-Wallis test was performed to test the differences among CERCIs statistically, and there are differences among organizations regarding adhocracy $(\mathrm{H}=18.23, \mathrm{p}<.05)$, and hierarchy $(\mathrm{H}=6.99, \mathrm{p}<.05)$ types of culture (Table 5). 
Table 5. Kruskal-Wallis test output regarding differences among CERCIs

\begin{tabular}{|c|c|c|c|c|c|c|}
\hline \multicolumn{7}{|l|}{ Test Statistics ${ }^{\mathrm{a}, \mathrm{b}}$} \\
\hline & & & Clan & Adhocracy & Market & Hierarchy \\
\hline Chi-Square & & & 2,157 & 18,227 & 2,023 & 6,992 \\
\hline Df & & & 2 & 2 & 2 & 2 \\
\hline Asymp. Sig. & & & 0,340 & 0,000 & 0,364 & 0,030 \\
\hline Monte Carlo & Sig. & &, $339^{c}$ &, $000^{c}$ &, $363^{\mathrm{c}}$ &, $027^{\mathrm{c}}$ \\
\hline \multirow[t]{2}{*}{ Sig. } & $99 \%$ & Lower Bound & 0,327 & 0,000 & 0,350 & 0,023 \\
\hline & $\begin{array}{l}\text { Confidence } \\
\text { Interval }\end{array}$ & Upper Bound & 0,351 & 0,000 & 0,375 & 0,031 \\
\hline
\end{tabular}

a. Kruskal Wallis test

b. Grouping variable: Organization

c. Based on 10000 samples tables with starting seed 2000000.

Mann-Whitney tests were used to follow up these findings (Field, 2009). A Bonferroni correction was applied, and so all effects are reported at a .0167 level of significance. Only between CERCI 1 and the others, we can find statistical differences, but not between CERCI 2 and CERCI 3 (Table 6).

CERCI 1 and CERCI 2 appear to be different regarding the adhocracy $(\mathrm{U}=818, \mathrm{r}=-.28)$ and hierarchy $(\mathrm{U}=887.5, \mathrm{r}=-.23)$ type of cultures, with an intermediate effect regarding the organization. Between CERCI 1 and CERCI 3 there is only a difference regarding adhocracy type of culture $(U=673.5, r=-0.39)$, also with an intermediate effect regarding the organization, slightly higher than between the former organizations. We can conclude that there are differences between the organizations regarding some culture types, and therefore, the Competing Values Framework can also be used in SEO.

Table 6. Mann-Whitney test and size effect results

\begin{tabular}{|c|c|c|c|}
\hline & & Adhocracy & Hierarchy \\
\hline \multirow{4}{*}{ CERCI 1 and CERCI 2} & Mann-Whitney U & 818,00 & 887,50 \\
\hline & $\mathrm{Z}$ & $-2,882$ & $-2,405$ \\
\hline & sig & 0,004 & 0,016 \\
\hline & Size effect (r) & $-0,28$ & $-0,23$ \\
\hline \multirow{4}{*}{ CERCI 1 and CERCI 3} & Mann-Whitney U & 673,50 & 992,50 \\
\hline & $\mathrm{Z}$ & $-4,03$ & $-1,89$ \\
\hline & sig & 0,000 & 0,059 \\
\hline & Size effect (r) & $-0,39$ & $-0,18$ \\
\hline \multirow{4}{*}{ CERCI 2 and CERCI 3} & Mann-Whitney U & 634,50 & 641,50 \\
\hline & $\mathrm{Z}$ & $-0,350$ & $-0,272$ \\
\hline & sig & 0,726 & 0,786 \\
\hline & Size effect (r) & $-0,04$ & $-0,03$ \\
\hline
\end{tabular}

Significance critical value $<.0167$

\section{Discussion}

The purpose of this article is to assess SEO's organizational culture dimension, and test if the Competing Values Framework (CVF) was an adequate model. Findings revealed that the three CERCIs studied have a balanced type of culture, that is, there is not a prominent kind, regarding the other. Even if the graphic representation is slightly different, the analysis of the results using the model's qualitative instructions, do not differentiate, neither the importance of types of culture within each CERCI, neither, the CERCIs among them. 
In this research, we introduced a statistical procedure to analyze the differences between culture types. The means show that, in general, clan culture is predominant regarding the other kinds of culture, which contradicts the framework's authors type of analyses. These results enable three discussion points. The first one is the analysis type that should be carried out to have a more rigorous output of framework, and to be able to manage culture accordingly. The second has to do with the fact that there seem to be differences among organizations, concerning reported culture types; thus, organizational differentiation regarding culture appears to be possible using the Competing Values Framework. And finally, the content itself, concerning the type of culture that is found.

The type of analysis proposed by Cameron and Quinn (2011) is of a qualitative nature (one-point difference among culture types), not taking into account the number of responses, neither the variability they may have. One of the most valuable features of this framework is its relation with managerial action, namely, leadership skills that contribute to increasing the presence of certain types of cultures, and steps to take to change the culture in a particular direction (Cameron \& Quinn, 2011). Being one of the most used and relevant models used in the history of management (Have et al., 2003) enables comparison and benchmark regarding numerous organizational variables, namely, organizational performance (Gregory et al., 2009). These findings may be significant to the usage of this model across organizations: to determine if there are differences, if action should be taken, as well as to describe in a more precise way the organizational profile of an organization.

A statistical analysis of the differences among cultures is a more accurate manner to determine if there are differences among organizations, analysing if the differences are similar. In these three case studies, even though there seems to be a general distinction between clan culture and the others, distinguishing this type of culture as prominent, there are still differences in the size effect: CERCI 2 and CERCI 3 have higher differences than CERCI 1. Also, CERCI 1 is different from the others because it shows differences between adhocracy and hierarchy and between market and hierarchy pairs of culture types. These results make CERCI 1 different from the others. Although the history of the CERCIs is not much different, there are some differences regarding the demographics: CERCI 1 is bigger and serves more population than the others. CERCI 2 and CERCI 3 are more alike, and therefore the culture may be similar. These differences also account for the pertinence of the Competing Values Framework usage in SEO.

Regarding the type of organizational culture, clan culture is the most prominent type, among the presented case-studies. Authors' model refers that there is not a type of culture that is better than others, throughout the organization's life cycle it can vary (Cameron \& Quinn, 2011). A recent meta-analysis in for-profit organizations also demonstrates that all culture types are related to organizational effectiveness (Hartnell, Ou, \& Kinicki, 2011), even if clan culture is more consistent with organizational effectiveness (Gregory et al., 2009). Clan culture being the predominant culture means that the collaborators understand that the highlight is in the relation established between the organization and the employees, is teamwork, involvement and organizational commitment (Gregory et al., 2009; Quinn \& Rohrbaugh, 1983). This type of culture is also consistent with the underlying assumptions and values of SEO, such as being of a collective nature, thus with a shared power (Parente, 2010), and developing people towards shared goals (Boone, 2014; Orsi et al., 2005). Consequently, the clan type of culture may be of more significant presence among all of these case studies.

The most conclusive test to make regarding the usage of a model to a different context is to analyze if, when applied, there are differences among different subjects. Findings refer to differences among organizations regarding adhocracy and hierarchy, and post hoc tests, confirm that there are only differences between CERCI 1 and the other organizations, and no significant 
relationship appeared between CERCI 2 and CERCI 3. These differences and similarities are parallel to the differences and similarities found when testing for differences within each organization. CERCI 1 was the most different organization, and CERCI 2 and CERCI 3 had the same type of differences and similarities, which may be due, as mentioned before, to their demographic characteristics (see details in Table 1). These differences between organizations enable the possibility of usage of the Competing Values Framework beyond the for-profit sector.

\section{Final remarks}

The present study sought to analyze the organizational culture in the SEO, specifically in CERCIs, applying the Competing Values Framework, as well as to test it's adequacy to the sector.

The importance of this study is related with the specificity of these NPOs, working in the area of the mental health and/or intellectual disabilities, and the shortage of studies in this specific area, particularly in the analysis of the organizational culture. As far as we know, the Competing Values Framework, a well-known model in for organizational culture study in the for-profit sector (Have et al., 2003) has not yet been applied to the social economy.

The results from data of three case-studies, cooperatives that assist and educate disabled people, seem to support that Competing Values Framework is adequate to the social economy sector. Initially, the organizational culture data's analysis followed the qualitative instructions of the model's authors (Cameron \& Quinn, 2011). Findings reveal that there are no differences to be reported. We introduced a statistical procedure on the same data, and significant differences appear regarding culture types within each organization: clan culture is predominant when comparing to the other types of culture. This result contradicts the original and generalized way of measuring culture in the Competing Values Framework. The way to assess culture in the model is especially important, not only because of the theoretical analysis and classification of culture but also because of the managerial implications it might have since this is a framework that is extensively used for organizational development (Cameron \& Quinn, 2011; Have et al., 2003). This is a major implication of this paper since it brings to light the importance of statistical testing to accurately define the cultural profile of an organization. Another important conclusion is the coherence of the most prominent culture in these casestudies (clan culture) with the nature and values of SEO: people development towards a shared goal and the participative nature of management (Boone, 2014; Parente, 2010). This coherence also helps to ground the adequacy of Competing Values Framework to the social economy sector. There are also statistical differences between CERCI 1 and 2, regarding adhocracy and hierarchy types of culture, and CERCI 1 and 3 regarding adhocracy culture. The discrepancies between cases show the framework's sensibility for this type of organizations.

This study enables the expansion of the use of this model, and for the scientific development of research on the topic. In a managerial perspective, this study contributes to the organizations which offer services in the mental disabilities field, and to their ability to manage their culture, contributing to the development and improvement.

The main limitations of this study concern the small inquired population not only in what regards cooperatives but also regarding the social economy sector. Although the results cannot be generalized for the entire population of the CERCI, cooperatives or SEO, this study represents an important starting point on the extension of Competing Values Framework study on the non-profit sector.

Given the relevance of this theme and the promising results of this study, the research could be widened to a higher number of CERCIs, to get a representative sample, as well as 
involving other types of non-profit organizations that act in the same sector, to get more accurate and consistent research. Being the multiple cases approach an adequate manner to study the theme; it would be relevant to complement the analysis of each case with interviews with key players of the studied organizations. The interviews could be conducted a priori or posteriori for the enrichment and better understanding of the results obtained through the remaining data collection. Moreover, it would be pertinent to compare the organizational performance with the culture and to compare the cases.

\section{Acknowledgement}

Ana C. Rodrigues e Marisa R. Ferreira gratefully acknowledges financial support from FCT- Fundação para a Ciência e Tecnologia (Portugal), national funding through projects UIDB/05422/2020 and UIDB/04728/2020.

\section{References}

Álvarez González, L. I., \& Sanzo Pérez, M. J. (2009). Organizational changes and dynamics of today's foundations. International Review on Public and Nonprofit Marketing, 6(1), 6374. https://doi.org/10.1007/s12208-009-0026-9

Bligh, M. C., \& Hatch, M. J. (2011). If I Belong, Do I Believe? An Integrative Framework for Culture and Identification. Journal of Psychological Issues in Organizational Culture, 2(1), 35-53. https://doi.org/10.1002/jpoc

Boerner, S., \& Jobst, J. (2011). Stakeholder Management and Program Planning in German Public Theaters. Non-profit Management and Leadership, 22(1), 67-84. https://doi.org/10.1002/nml

Boone, S. (2014). Using Organizational Learning to Increase Operational and Conceptual Mental ModelsWithin Professional Learning Communities. Journal of Psychological Issues in Organizational Culture, 5(3), 85-99. https://doi.org/10.1002/jpoc

Buendía-Martínez, I., álvarez-Herranz, A., \& Menéndez, M. M. (2020). Business cycle, SSE policy, and cooperatives: The case of Ecuador. Sustainability (Switzerland), 12(13), 120. https://doi.org/10.3390/su12135485

Calderón-Milán, M. J., Calderón-Milán, B., \& Barba-Sánchez, V. (2020). Labour inclusion of people with disabilities: What role do the social and solidarity economy entities play? Sustainability (Switzerland), 12(3). https://doi.org/10.3390/su12031079

Cameron, K. S., \& Quinn, R. E. (2011). Diagnosing and Changing Organizational Culture: Based on the Competing Values Framework (3rd ed.). Jossey-Bass Wiley.

Carvalho, A. O., Ferreira, M. R., \& Silva, P. (2019). Partners in a caring society - a non-profit organization case study. Economics \& Sociology, 12(2), 129-146. https://doi.org/10.14254/2071-789x.2019/12-2/8

Chaves-Avila, R., \& Gallego-Bono, J. R. (2020). Transformative policies for the social and solidarity economy: The new generation of public policies fostering the social economy in order to achieve sustainable development goals. The European and Spanish cases. Sustainability (Switzerland), 12(10). https://doi.org/10.3390/SU12104059

Chaves, R., \& Monzón, J. L. (2012). The Social Economy in the European Union (European C). https://doi.org/10.1787/9789264039889-en 
Chumg, H. F., Cooke, L., Fry, J., \& Hung, I. H. (2015). Factors affecting knowledge sharing in the virtual organisation: Employees' sense of well-being as a mediating effect. Computers in Human Behavior, 44(March), 70-80. https://doi.org/10.1016/j.chb.2014.11.040

FENACERCI. (2015). Relatório de atividades FENACERCI.

Ferreira, M. R., Rodrigues, A. C., \& Marques, C. P. (2015). Organizational culture in cooperatives: An exploratory approach. Proceedings of the 26th International Business Information Management Association Conference - Innovation Management and Sustainable Economic Competitive Advantage: From Regional Development to Global Growth, IBIMA 2015.

Field, A. (2009). Discovering Satistics Using SPSS (3rd ed.). SAGE Publications Inc.

Giffords, E. D., \& Dina, R. P. (2003). Changing Organizational Cultures: The Challenge in Forging Successful Mergers. Administration in Social Work, 27(1), 69-81. https://doi.org/10.1300/J147v27n01

Gregory, B. T., Harris, S. G., Armenakis, A. A., \& Shook, C. L. (2009). Organizational culture and effectiveness: A study of values, attitudes, and organizational outcomes. Journal of Business Research, 62(7), 673-679. https://doi.org/https://doi.org/10.1016/j.jbusres.2008.05.021

Guerra, I. (2008). Pessoas com Deficiência : Mobilidade, Educação e Trabalho. Lisboa.

Hartnell, C. A., Ou, A. Y., \& Kinicki, A. (2011). Organizational Culture and Organizational Effectiveness: A Meta-Analytic Investigation of the Competing Values Framework's Theoretical Suppositions. Journal of Applied Psychology, 96(4), 677-694.

Have, S. ten, Have, W. ten, \& Stevens, F. (2003). Key Management Models: The Management Tools and Practices that Will Improve Your Business. Pearson Education.

INE, \& CASES. (2013). Conta Satélite da Economia Social 2010.

Jaskyte, K. (2010). An Exploratory Examination of Correlates of Organizational Culture. Administration in Social Work, 34(5), 423-441. https://doi.org/10.1080/03643107.2010.518518

Jaskyte, K., \& Dressler, W. (2005). Organizational Culture and Innovation in Nonprofit Human Service Organizational Culture and Innovation in Nonprofit Human Service Organizations. Administration in Social Work, 29(2), 23-41. https://doi.org/10.1300/J147v29n02

Kellner, A., Townsend, K., \& Wilkinson, A. (2016). 'The mission or the margin?' A highperformance work system in a non-profit organisation. The International Journal of Human Resource Management, 5192(June), 1-22. https://doi.org/10.1080/09585192.2015.1129636

Krajcsák, Z. (2018). Making High Committed Workplaces by Strong Organizational Values. Journal of Human Values. https://doi.org/10.1177/0971685818764064

Lopes, A. (2010). A Cultura Organizational em Portugal: De Dimensão Oculta a Principal Activo Intangível. Gestão e Desenvolvimento, 17-18, 3-26.

Lopes, A., \& Reto, L. (1988). Cultura de empresa - Moda, metáfora ou paradigma. Revista de Gestão, Gabinete de Estudos de Gestão Do ISCTE, 2-3, 25-37.

Martínez, A. P. (2009). Cultura organizational : algunas reflexiones a la luz de los nuevos retos Organizational Culture: Some Reflections in the Light of New Challenges. Revista Venezolana De Gerencia, 14(46), 183-194.

Martins, R. (2010). Comunicação de Gestão da Mudança: como (Re)Criar uma Organização de Confiança no Terceiro Sector. In C. Azevedo, R. C. Franco, \& J. W. Meneses (Eds.), Gestão das Organizações sem Fins Lucrativos. Porto: Imoedições.

Monzón-Campos, \& Chaves-Ávila, R. (2012). The social economy in the European Union. https://doi.org/10.1787/9789264039889-en 
Neves, J. (2000). Clima Organizational, Cultura Organizational e Gestão de Recursos Humanos. Lisboa: RH Editora.

OBESP. (2011). A Economia Social: Conceito Proposto Pelo OBESP. Retrieved from http://www.cases.pt/0_content/actividades/obesp/OBESP_Conceito_de_Economia_soci al_09_DEZ_2011.pdf

Orsi, A., Marino, E., Rossi, L., Bertoia, N., \& Shiniashiki, R. (2005). Cultura Organizational e Terceiro Setor. Revista Gestão \& Conhecimento, 3(1), 34-55.

Parente, C. (2010). Gestão de Pessoas nas OSFL. In C. Azevedo, R. C. Franco, \& J. W. Meneses (Eds.), Gestão das Organizações sem Fins Lucrativos. Porto: Imoedições.

Pinho, J. C., Rodrigues, A. P., \& Dibb, S. (2014). The role of corporate culture, market orientation and organisational commitment in organisational performance. Journal of Management Development, 33(4), 374-398. https://doi.org/http://dx.doi.org/10.1108/BIJ-10-2012-0068

Pinto, P. C., \& Pinto, T. J. (2017). Pessoas com deficiência em Portugal. In Observatório da Deficiência e Direitos Humanos. https://doi.org/10.1016/j.ympev.2013.08.013

Płachciak, A. (2009). Sustainable development - The way of building just society. Economics \& Sociology, 2(1), 105-110. https://doi.org/10.14254/2071-789X.2009/2-1/10

Potts, J., \& Hartley, J. (2015). How the Social Economy Produces Innovation. Review of Social Economy, 73(3), 263-282. https://doi.org/10.1080/00346764.2015.1067756

Quinn, R. E., \& Rohrbaugh, J. (1983). A spatial model of effectiveness criteria: Towards a competing values approach to organizational analysis. Management Science, 29(3), 363377.

Rodrigues. (2015). Movimento CERCI em Portugal : 40 anos de vida, do movimento social à institucionalização. Universidade Lusíada de Lisboa.

Rodrigues, A., \& Caetano, A. (2013). A Competing Values Framework Approach on Growth and Performance in Micro Firms. Entrepreneurship Summer University at ISCTE-IUL. Lison.

Rodrigues, A., \& Caetano, A. (2015). An organizational culture approach to performance in information technology micro-firms. 26th International Business Information Management Association, 1-5. Madrid.

Romero, A. J., \& Pérez, M. (2003). Organizational Culture, Individual Differences and the Participation System in Cooperativism of Associated Workers in Andalusia, Spain. Annals of Public and Cooperative Economics, 74(2), 283-320. https://doi.org/10.1111/1467-8292.00225

Ruwer, L. M. E., \& Canoas, J. W. (2009). Gestão de Pessoas em Organizações do Terceiro Setor: Especificidades dos Recursos Humanos, Perspectivas e Desafios - Notas Introdutórias. Serviço Social \& Realidade, 18(2), 107-132.

Santos, N. M. B. F. dos. (1998). Cultura e desempenho organizational: um estudo empírico em empresas brasileiras do setor têxtil. Revista de Administração Contemporânea, 2(1), 4776. https://doi.org/10.1590/S1415-65551998000100004

Sdrali, D., Goussia-Rizou, M., Giannouli, P., \& Makris, K. (2016). What motivates employees to engage in the social economy sector? A case study of Greek cooperative enterprises. International Journal of Social Economics, 43(12), 1334-1350. https://doi.org/10.1108/IJSE-10-2014-0212

Sonnino, R., \& Griggs-Trevarthen, C. (2013). A resilient social economy? Insights from the community food sector in the UK. Entrepreneurship \& Regional Development, 25(3-4), 272-292. https://doi.org/10.1080/08985626.2012.710268 
Souder, L. (2016). A Review of Research on Nonprofit Communications from Mission Statements to Annual Reports. VOLUNTAS: International Journal of Voluntary and Nonprofit Organizations, 27(6), 2709-2733. https://doi.org/10.1007/s11266-016-9699-y

Velden, M. Van Der, Alvarez, N., Sá, J. de, Meira, D., \& Ramos, E. (2014). A map of social enterprises and their eco-systems in Europe Country Report : Portugal. London.

Wellens, L., \& Jegers, M. (2014). Effective Governance in Non-profit Organizations: A Literature Based Multiple Stakeholder Approach. European Management Journal, 32(2), 223-243. https://doi.org/10.1016/j.emj.2013.01.007 